\title{
IAIN CURUP STUDENTS'SELF-ENDURANCE AND PROBLEMS IN ONLINE LEARNING DURING THE COVID-19 PANDEMIC
}

\section{KETAHANAN DIRI DAN KENDALA MAHASISWA IAIN CURUP SELAMA BELAJAR DARING DI MASA PANDEMI COVID-19}

\author{
Muhamad Uyun ${ }^{1}$, Idi Warsah ${ }^{2}$ * \\ Universitas Islam Negeri (UIN) Raden Fatah Palembang \\ Institut Agama Islam Negeri (IAIN) Curup \\ *Korespodensi: idiwarsah@gmail.com
}

\begin{abstract}
The transformation of learning from offline to online modes due to the Covid-19 pandemic has affected students' self-endurance in learning and the complexities of learning problems. Accordingly, this study was oriented towards investigating IAIN Curup students' self-endurance and the problems they faced during online learning. Grounded in a qualitative method, this study incorporated 20 IAIN Curup students selected purposively as the participants. They were interviewed on the basis of the study's foci. The data of interviews were analyzed using an interactive model. The findings demonstrated weak students' self-endurance in online learning. Psychologically, they felt under pressure. Physically, their eyes' condition got worse, and a few of them suffered from headache. They were psychologically bored as well less-concentrated, and they could not enjoy learning due to the limitation of social engagement in learning. Subsequently, as regards the problems faced during online learning, they had problems related to Internet's signals, budgeting for fulfilling Internet's needs, and difficulty in the search of learning resources, wherein the foregoing was categorized as a case of weak technological competence.
\end{abstract}

Keyword: Online learning, Self-endurance, Problems in online learning

\begin{abstract}
ABSTRAK
Pergantian moda pembelajaran dari luring ke daring yang secara instan dikarenakan pandemi Covid19 berdampak pada ketahanan diri dan kompleksitas kendala belajar. Dengan demikian, penelitian ini berfokus untuk mengungkap ketahanan diri mahasiswa IAIN Curup dan kendala yang mereka alami selama pemebelajaran daring. Berpayung pada metode kualitatif, penelitian ini melibatkan 20 orang mahasiswa IAIN Curup yang dipilih secara purposif sebagai partisipan. Mereka diwawancari terkait orientasi tujuan penelitian yang dimediasi oleh video call. Hasil wawancara dianalisa berbasis pada model interaktif. Temuan penelitian ini menggambarkan lemahnya ketahanan diri mahasiswa dalam pembelajaran daring. Secara psikologis, mereka tertekan. Secara fisik kesehatan mata mereka menurun, dan ada yang mengalami sakit kepala. Ketahanan fisik mereka menurun hingga menyebabkan kualitas psikis mereka juga menurun. Secara psikologis, mereka merasa jenuh, susah berkonsentrasi, dan tidak menikmati belajar karena terbatasnya keterlibatan dalam dimensi sosial saat belajar. Selanjutnya, terkait dengan kendala yang dialami selama pembelajaran daring, mereka mengalami kendala pada sinyal internet, kendala pembiayaan untuk membeli kuota internet, dan kendala sulitnya mencari referensi dalam proses pembelajaran daring, yang mana ini dikategorikan sebagai kendala lemahnya kompetensi berteknologi mahasiswa.
\end{abstract}

Kata Kunci: Pembelajaran daring, Ketahan diri, Kendala dalam pembelajaran daring. 


\section{PENDAHULUAN}

Wabah Covid-19 yang telah melanda 215 negara di dunia memberikan tantangan tersendiri bagi lembaga pendidikan (Ellis dkk., 2020), khususnya Perguruan Tinggi. Untuk melawan Covid-19, Pemerintah telah melarang masyarakat untuk berkerumun, mengerahkan pembatasan sosial (social distancing) dan menjaga jarak fisik (physical distancing), memakai masker dan selalu cuci tangan. Melalui Kementerian Pendidikan dan Kebudayaan, Pemerintah telah melarang perguruan tinggi untuk melaksanakan perkuliahan tatap muka (konvensional) dan memerintahkan untuk menyelenggarakan perkuliahan atau pembelajaran secara daring (Surat Edaran Kemendikbud Dikti No. 1 tahun 2020). Perguruan tinggi dituntun untuk dapat menyelenggarakan pembelajaran secara daring atau online (Firman and Rahman 2020).

$$
\text { Kementerian Pendidikan dan }
$$
Kebudayaan (Kemendikbud) sendiri sudah meminta kepada seluruh Perguruan Tinggi untuk memberi kemudahan pembelajaran di masa darurat Covid-19. Membantu Pemerintah dan masyarakat untuk melakukan pembelajaran dari rumah, bekerja dari rumah, serta melakukan pembatasan sosial untuk memutus mata rantai penyebaran Covid-19. Direktorat Jenderal Pendidikan Tinggi (Ditjen Dikti) juga mengimbau agar perguruan tinggi dengan otonomi yang dimilikinya dapat memberikan fleksibilitas dalam pelaksanaan pembelajaran jarak jauh di masa darurat Covid-19. Bentuk perkuliahan yang dapat dijadikan solusi dalam masa pandemi covid-19 adalah pembelajaran daring. Menurut Burke dan Cleaver (2019), salah satunya dengan menerapkan sistem Home Learning atau belajar di rumah. Beragam metode tidak konvensional bisa dijadikan pilihan, seperti dalam bentuk penugasan, esai, kajian pustaka, analisa data, proyek mandiri, dan lain-lain dengan memanfaatkan berbagai macam media pembelajaran seperti e-learning, google classroom, zoom dan aplikasi lainnya. Media pembelajaran elektronik (E-learning) adalah bukti kemajuan luar biasa dari peradaban manusia.

Pembelajaran daring merupakan pembelajaran yang menggunakan jaringan Internet dengan aksesibilitas, konektivitas, fleksibilitas, dan kemampuan untuk memunculkan berbagai jenis interaksi pembelajaran (Barclay dkk., 2018; HernándezLara \& Serradell-López, 2018; Huang, 2019). Penelitian yang dikakukan oleh Zhang dkk. (2004) menunjukkan bahwa penggunaan Internet dan teknologi multimedia mampu merombak cara penyampaian pengetahuan dan dapat menjadi alternatif pembelajaran yang dilaksanakan dalam kelas tradisional. Pembelajaran daring adalah pembelajaran yang mampu mempertemukan mahasiswa dan dosen untuk melaksanakan interaksi pembelajaran dengan bantuan internet (Martin dkk., 2018).

Pada tataran pelaksanaanya, pembelajaran daring memerlukan dukungan perangkat-perangkat mobile seperti 
smartphone atau telepon adroid, laptop, komputer, tablet, dan iphone yang dapat dipergunakan untuk mengakses informasi kapan saja dan dimana saja (Wei dkk., 2015). Pembelajaran secara daring telah menjadi tuntutan dunia pendidikan sejak beberapa tahun terakhir (Huang, 2019; Santos \& Cechinel, 2019; Wei dkk., 2019). Pembelajaran daring dibutuhkan dalam pembelajaran di era revolusi industri 4.0. Penggunaan teknologi mobile mempunyai sumbangan besar dalam lembaga pendidikan, termasuk di dalamnya adalah pencapaian tujuan pembelajaran jarak jauh (Gómez-Rey dkk., 2016). Berbagai media juga dapat digunakan untuk mendukung pelaksanaan pembelajaran secara daring. Misalnya, kelaskelas virtual menggunakan layanan dan applikasi pesan instan seperti WhatsApp. Pembelajaran secara daring bahkan dapat dilakukan melalui media social seperti Facebook dan Instagram. Pembelajaran daring menghubungkan peserta didik dengan sumber belajarnya (database, pakar/instruktur, perpustakaan) yang secara fisik terpisah atau bahkan berjauhan namun dapat saling berkomunikasi, berinteraksi atau berkolaborasi baik secara langsung/synchronous maupun secara tidak langsung/asynchronous (Santos and Cechinel 2019).

Bagimanapun juga, pembelajaran daring tidak begitu saja dengan mudah bisa dilaksankan, karena pasti akan selalu ada kendala baik prinsip pedagogis maupun teknis yang akan dialami oleh pihak guru atau dosen dan siswa atau mahasiswa. Misalnya, penelitian yang dilakukan oleh Huang (2019) menyoroti bahwa pembelajaran daring memberikan tantangan dalam aspek manajerial bagi pendidik. Gómez-Rey dkk. (2016) menyoroti bahwa pembelajaran daring cenderung memicu perbedaan persepsi dan ekspektasi antara pengajar dan pelajar. Penelitian yang dilakukan oleh Wei dkk. (2019) mengimplikasikan bahwa apabila pembelajaran daring tidak memenuhi tiga faktor utama, yaitu esensi kebergunaan atau kebermanfaatan dari platform yang digunakan, kemudahan yang dirasakan dalam penggunaan platform tersebut, dan lingkungan belajar yang mendukung, maka keberhasilan pembelajaran daring sulit dicapai.

Di sisi lain, pelajar juga akan mengalami kendala ketahan belajar. Morgan (2020) menggaungkan apabila pembelajaran daring tidak dikontrol dengan sistem pedagogik yang baik, murid bisa mengalami tekanan psikologis. Hal ini sangat wajar terjadi karena pembelajaran daring merupakan transformasi moda belajar yang bersamaan dengannya juga merupakan transformasi prinsip pedagogik, metode belajar mengajar, serta cara memperlakukan murid. Dalam pembelajaran biasa (luring), idealnya prinsip belajar didasari oleh pendekatan sosio-kultural dan pedagogik kritis, sebagai landasan teori pedagogik yang paling mutakhir di abad 21 (Gil-Glazer 2017; Schwimmer 2019; Pittard 2016). Sebagaimana pendekatan pedagogis ini, maka murid akan terarahkan menjadi pelajar yang kritis (Warsah dkk., 2021), bersikap interkultural (Morganna dkk., 2020; Warsah 
dkk., 2019b), memiliki kompetensi sosial yang baik (Warsah, 2018, 2020a; Warsah dkk., 2020; Warsah \& Uyun, 2019), serta memiliki kualitas keberagamaan yang baik (Warsah, 2020b, 2020c; Warsah dkk., 2019a). Sealnjutnya, dalam pembelajaran dengan moda luring seperti biasa, pengajar sudah biasa dan terlatih dalam memperlakukan murid dengan kasih sayang (Warsah 2020c). Namun, dalam pembelajaran daring, semua aspek pembelajaran luring seperti yang disebutkan barusan terpaksa harus ikut bertransformasi sesuai dengan moda daring, yang tentunya memberi tantangan bagi guru dan murid. Sebagai akibatnya, ketahanan belajar murid bisa menurun drastis baik secara fisik maupun psikis (Dinh and Nguyen 2020; Kidd and Murray 2020). Berbasis pada konteks ini, penelitian ini dilakukan untuk mengungkap dua hal, yaitu 1) bagaimana ketahanan mahasiswa IAIN Curup selama pembelajaran daring? Dan 2) apa kendala yang dialami mahasiswa IAIN Curup dalam pembelajaran daring?

\section{METODE}

Penelitian ini mengadaptasi paradigma naturalistik (Creswell 2007) sebagai kaca mata besar dalam memandang data penelitian. Dalam bahasa lain, ini merupakan penelitian kualitaitif (Fraenkel dkk., 2012). Desain yang digunakan dalam penelitian ini adalah penelitian kualitatif deskriptif. Ada dua tujuan utama dari penelitian ini. Pertama, penelitian ini berusaha mengungkap informasi tentang ketahanan mahasiswa Institut Agama Islam
Negeri (IAIN) Curup selama pembelajaran daring. Kedua, penelitian ini menggali informasi tentang kendala yang dialami mahasiswa IAIN Curup selama pemebelajaran daring. Penelitin ini melibatkan 20 orang mahasiswa IAIN Curup dari berbagai jurusan dan berbagai level. Mereka dipilih secara purposif. Landasan kriteria pelibatan mereka sebagai partisipan meliputi beberapa indikator. Pertama, mereka cukup berpengalaman dalam mengikuti pembelajaran daring. Kedua, mereka bisa diakses dengan mudah melalui media sosial untuk keperluan pengambilan data. Ketiga, mereka bersedia menjadi partisipan dalam penelitian ini.

Data dalam penelitian ini dikumpulkan menggunakan teknik wawancara. Orientasi pertanyaan wawancara dipusatkan pada dua tema besar, yaitu tentang ketahanan belajar selama pembelajaran daring, dan tentang kendala yang partisipan hadapi selama pembelajaran daring berlangsung. Data hasil wawancara selanjutnya dianalisa menggunakan model interaktif sebagaimana yang disarankan oleh Miles dkk. (2014). Ada empat elemen proses analisis data yang dituntun oleh model interaktif ini, yaitu pengumpulan data, pemadatan data, penyajian data, dan penarikan simpulan.

Berbasis pada model analisis interaktif, pada element pengumpulan data, sebagaimana sudah dijelaskan sebelumnya bahwa data dikumpulkan menggunakan teknik wawancara yang dilakukan secara daring menggunakan video call melalui aplikasi Whatsapp. Hal ini dilakuukan 
mempertimbangkan kondisi pandemi Covid19 yang tidak memungkinkan peneliti untuk bertemu dan mewawancari partisipan melalui moda tatap muka. Terkait dengan pemadatan data, data hasil wawancara dikategorikan berdasarkan tema-tema yang representatif. Seluruh data wawancara sudah dikelompokkan berbasis tema terlebih dahulu agar nantinya data dapat disajikan ke dalam bentuk susunan informasi yang terkonsep. Terkait dengan penyajian data, data disajikan kedalam bentuk penjelasan yang terkonsep berdasarkan tematema yang sudah dimunculkan secara representatif. Dalam setiap penjelasan data, cuplikan beberapa transkrip wawancara dengan partisipan juga ditampilkan. Transkriptranskrip tersebut dipilih yang paling representatif untuk mewakili seluruh informasi dari partisipan yang menegosiasikan diskursus yang sama. Sebagai tahapan terakhir, seluruh informasi mengenai temuan penelitian ini disimpulkan dengan bahasa yang mudah dimengerti namun akademis.

\section{HASIL PEMBAHASAN}

\subsection{Gambaran Umum Terkait Media}

\section{Pembelajaran Daring di IAIN Curup}

Sebagai gambaran umum, kondisi pembelajaran daring di IAIN Curup menggunakan berbagai opsi platforms atau aplikasi belajar daring seperti website (quizez, dll), youtube dan situs berbagi vidio yang lain, google classroom, aplikasi webex, tik-tok dan smule, WhatsApp, zoom, dan juga google meet. Terdapat juga beberapa aplikasi yang paling sering digunakan yaitu google classroom, WhatsApp, zoom dan google meet. Sedangkan untuk aplikasi paling favorit tentu saja jatuh kepada aplikasi WhatsApp, sebab aplikasi ini merupakan yang termurah dan dalam peng-aksesannya tidak memerlukan sinyal yang terlalu kuat. Menurut mereka, pembelajaran dalam bentuk konferensi video telah menghabiskan banyak kuota data, sementara diskusi online melalui applikasi pesan instan tidak membutuhkan banyak kuota. Presentasi berikut merupakan diagram presentase aplikasi yang paling sering digunakan untuk sistem pembelajaran daring di IAIN Curup. 




Gambar 1: Diagram tentang aplikasi yang sering digunakan dalam pembelajaran daring di IAIN Curup

\subsection{Ketahanan Mahasiswa IAIN Curup dalam Pembelajaran Daring}

Data tentang ketahanan mahasiswa IAIN Curup dalam mengikuti pembelajaran daring dikumpulkan melalui wawancara yang dimediasi oleh video call, sebab proses wawancara berlangsung ketika kebijakan PSBB diberlakukan. Berdasarkan hasil wawancara terkait isu ini, ada beberapa tema yang merepresentasikan kondisi ketahanan mahasiswa IAIN Curup dalam pembelajaran daring. Tema-tema itu adalah: 1) aspek psikologis mahasiswa tertekan, secara fisik kesehatan mata menurun, dan mengalami sakit kepala. 2) Ketahanan fisik mahasiswa menurun hingga menyebabkan kualitas psikis mereka menurun. 3) secara psikologis, mahasiswa merasa bosan. 4) Secara psikologis, mahasiswa susah berkonsentrasi. 5) Kualitas psikologis mahasiswa menurun karena terbatasnya keterlibatan dalam dimensi sosial saat belajar.

Tema pertama dari data wawanacara (aspek psikologis mahasiswa tertekan, secara fisik kesehatan mata menurun, dan mengalami sakit kepala) tergambarkan dalam berbagai ekspresi kompleksitas masalah fisik dan psikologis yang dialami mahasiswa saat pembelajaran daring. Kompleksitas tersebut dapat dilihat pada cuplikan wawancara berikut:

\footnotetext{
"Sebagian besar dari informan yang memberikan tanggapan, menyatakan tidak kuat secara fisik dan psikis karena situasi pandemi covid-19 yang serba di bawah tekanan dan juga ketidaksiapan mental mereka dalam menghadapinya". (Wawancara dengan Anton, Jumat, 8 Januari 2021, via video call WA)
} 
"Secara fisik saya merasa baik. Sedangkan dari segi psikis saya merasakan tekanan, karena tugas setiap harinya yang jarak pengumpulan tugas satu dan tugas lain sangat mepet". (Wawancara dengan Anggraini, Jumat, 8 Januari 2021, via video call WA).

"Kondisi fisik banyak berubah selama pembelajaran daring terutama kesehatan mata. Selain itu dalam segi psikis, bisa menjadi tertekan dan mudah panik. Belajar jarak jauh mengakibatkan mahasiswa menggunakan handphone mereka secara terus menerus. Hal ini tentu saja berdampak pada kesehatan bila terlalu lama menatap layar handphone, dikhawatirkan bukannya sakit terinfeksi virus corona tapi malah sakit karena terlalu lama terkena radiasi HP. Belum lagi sistem daring bisa mengakibatkan moral mahasiswa menurun, terbukti dengan banyaknya mahasiswa yang tertidur saat kelas berlangsung". (Wawancara dengan Apriani, 23 Desember 2020, Via video call WA).

"Fisik untuk bulan pertama masih kuat, tapi akhir-akhir ini kondisi badan menurun, gejala yang paling awal yaitu pada mata saya yang perih dan merah mungkin karena cahaya dari handphone atau pun laptop. Sedangkan kondisi psikis saya bukan tambah baik malah semakin menurun akibat tugas yang menumpuk dan tekanan dari dosen karena harus mengejar deadline tugas". (Wawancara dengan Ismail, Jumat, 8 Januari 2021, via video call WA).

"Secara mental saya sedikit tertekan karena banyaknya tugas, rasa panik dan susah mengatur waktu, secara fisik saya mulai sering sakit kepala dan kesulitan tidur". (Wawanara dengan Apriani, Jumat, 8 Januari 2021, via video call WA).

"Secara fisik dan psikis saya sangat kurang suka dengan pembelajaran daring. Fisik saya tidak tahan akan kemalasan yang kadang menyerang, akibat banyak kuliah sambil rebahan. Begitupun dengan psikis, melihat kedaan seperti ini, Memang kita dituntut untuk lebih mandiri dan lebih pandai me-manage segala hal. Kendati demikian tidak bisa dipungkiri bahwasanya untuk mendapatkan pemahaman yang maksimal tentu diri ini memerlukan penerapan pengajaran yang pas dari dosen, tidak hanya melulu diberikan tugas tanpa penjelasan, resuman tanpa perhatian, dan makalah tanpa penghargaan. Jadi padatnya kewajiban, disandingkan dengan kebutuhan yang tak 
memuaskan ditambah dengan tugas yang tak berselang. Maka dari itu secara psikis saya cukup terganggu dengan keadaan belajar seperti ini”. (Wawancara dengan Hariansya, Jumat, 8 Januari 2021, via video call WA).

"Ketahanan fisik dan psikis saya ketika belajar daring selama masa pandemi ini untuk ketahan fisik Alhamdulillah cukup kuat, tetapi tidak untuk ketahan psikis saya rasa berkebalikannya. Karena dengan adanya pembelajaran daring dan kondisi pandemi ini ketahanan psikis terkadang tidak selalu baik-baik saja. Faktornya di pengaruhi oleh banyak hal, serta banyak pelajaran yang banyak tidak mengerti membuat kondisi psikis juga tidak baik". (Wawancara dengan Amelia, Jumat, 8 Januari 2021, via video call WA).

"Pusing intinya". (Wawancara dengan Fajri, Jumat, 8 Januari 2021, via video call WA).

Transkrip wawancara di atas, secara singkat menggambarkan bahwa dalam pembelajaran daring, mereka mengalami tekanan psikologis, mengalami penurunan kesehatan mata, mengalami sakit kepala, mengalami penurunan kedisiplinan belajar, mengalami kesusahan dalam pembelajaran daring karena banyak instruksi dan tugas belajar yang tidak begitu jelas. Hal ini sejalan dengan argumentasi Morgan (2020) bahwa pelajar akan cenderung mengalami penurunan kualitas psikologis dan fisik dalam pembelajaran daring apabila proses dan sistem pembelajaran daring tidak dikontrol dalam prinsip manajerial pembelajaran yang ideal. Tema ke dua dari data wawancara (ketahanan fisik mahasiswa menurun hingga menyebabkan kualitas psikis mereka menurun) terlukiskan dalam cuplikan transkrip wawancara berikut:

\footnotetext{
"Saya merasa lelah secara fisik dan psikis, karena materi dari dosen yang sulit dipahami. Oleh karena itu saya hanya mengawali semuanya dengan niat yang tulus ingin menuntut ilmu, karena semua berawal dari niat, innama'amalul bin niat". (Hasanah, L., \& Dayang, S., Jumat, 8 Januari 2021, via video call WA)
}

"Ketahanan saya di masa pandemi sedikit menurun dan lumayan melelahkan karena banyak sekali tugas. Bisa dibilang sulit tapi masih mampu untuk di kerjakan". (Mentari, L., Jumat, 8 Januari 2021, via video call WA).

"Ketahanan fisik dan psikis agak kurang baik karena pada kesehatan fisik mahasiswa tentu saja jarang melakukan kegiatan karena banyak berdiam diri di rumah saja dan jarang melakukan kegiatan fisik yang berat. 
Sedangan dengan psikis saya merasa terganggu karena tekanan terkurung di dalam rumah". (Shaputri, R., Jumat, 8 Januari 2021, via video call WA).

"Secara fisik kurang tahan karena saya kelelahan terus menerus menatap layar handphone. Secara psikis juga tidak efektif karena sulit untuk memahami materi". (Novita, D., Jumat, 8 Januari 2021, via video call WA).

"Benar-benar terkuras habis ketahanan fisik maupun psikis saya". (Rahmah, N., Jumat, 8 Januari 2021, via video call WA).

"Ketahan saya cukup kuat karena psikis bisa memengaruhi fisik jadi jujur selama pembelajaran daring saya pernah drop dua minggu mungkin karena beban fikiran dan sering bergadang mengerjakan tugas". (Mutmainatun, K., Jumat, 8 Januari 2021, via video call WA).

Transkrip wawancara diatas menyajikan beberapa informasi yang menggambarkan tentang kondisi menurunnya ketahanan mahasiswa dalam pembelajaran daring. Seperti yang diinformasikan, mahasiswa merasa lelah baik secara fisik maupun psikis karena prosees pembelajaran daring yang begitu kompleks, mengalami penurunan kekuatan fisik karena kurang gerak, merasa tertekan secara psikologis karena terisolasi dari kehidupan sosial, merasa susah memahami materi yang diakibatkan oleh nuansa psikologis yang tidak ideal, dan merasakan efek bahwa ketahanan fisik menurun yang diakibatkan oleh kondisi psikis yang tertekan saat belajar. Temuan ini sejalan dengan penelitian yang dilakukan oleh Kruszewska dkk. (2020) yang salah satu aspek temuannya menggambarkan bahwa, selain kendala terkait teknolgi, pembelajaran daring juga menyisakan kendala kesehatan bagi murid. Tema ketiga dari data wawancara (secara psikologis, mahasiswa merasa bosan) tergambarkan dalam cuplikan transkrip berikut ini:

"Belajar daring terasa begitu membosankan". (Manda, D., Jumat, 8 Januari 2021, via video call WA).

"Ketika pertama kali belajar daring menurut saya terasa menyenangkan, namun lama-kelamaan menjadi bosan. Ketahanan fisik saya oke, tapi kesehatan psikis saya menurun. Menurut saya hal ini dikarenakan terlalu banyak tugas dan sebagian dari tugasnya tidak di terangkan secara jelas bagaimana aturan mengerjakannya". (Lestari, Jumat, 8 Januari 2021, via video call WA).

"Bored, saya merasa bosan". (Majid, A., Jumat, 8 Januari 2021, via video call WA). 
"Sangat-sangat merasa terganggu sebab tugas yang sangat banyak dan kebosanan akibat di dalam rumah dan tidak diberi kepastian sampai kapan harus menunggu masa pandemi berakhir”. (Soleh, R., Jumat, 8 Januari 2021, via video call WA).

"Dengan adanya belajar daring ini, walau fleksibel tapi berdapak pada menurunnya semangat belajar para siswa. Tak jarang banyak mahasiswa yang bermalas-malasan di rumah, tugas semakin menumpuk dan jarang dikerjakan. Namun karena hal ini merupakan aturan pemerintah demi mencegah penyebaran virus corona maka mau tidak mau harus tetap dijalankan dengan penuh keikhlasan”. (Siregar, R., Jumat, 8 Januari 2021, via video call WA).

Dari cuplikan transkrip wawancara di atas, ada beberapa penyebab mahasiswa merasa bosan dalam pembelajaran daring, yaitu pembelajaran daring cenderung berafiliasi dengan banyaknya tugas, tugas yang diberikan oleh dosen cenderung tidak begitu jelas spesifikasinya, dan kondisi belajar di rumah yang cenderung memicu mahasiswa untuk bermalas-malasan. Kondisi ini terjadi karena sistem belajar daring adalah sistem baru bagi dosen dan mahasiswa IAIN Curup sehingga kendal-kendala ini terjadi. Sebagaimana yang digaungkan oleh Wei dkk. (2019), ada tiga kondisi yang harus terpenuhi untuk menghindari efek negatif dari pembelajaran daring, yaitu esensi kebergunaan atau kebermanfaatan platform jelas dipahami oleh pengajar dan pelajar, adanya kemudahan yang dirasakan dalam penggunaan platform tersebut, dan lingkungan belajar daring yang ideal. Tiga kondisi ini kelihatannya belum mampu terpenuhi dalam sistem pembelajaran daring yang dojalankan di IAIN Curup, sehingga secara psikologis mahasiswa tidak antusias dan merasa bosan dengan pembelajaran daring. Tema keempat dari data wawancara (Secara psikologis, mahasiswa susah berkonsentrasi) terlukiskan dalam cuplikan transkrip wawwancara berikut ini:

"Kondisi saya belajar daring di masa pandemi ini sungguhlah tidak nyaman. Pertama terhambat sinyal lalu saya tidak konsentrasi sebab banyak gangguan di rumah". (Novika, S., Jumat, 8 Januari 2021, via video call WA).

"Saya merasa kurang fokus". (Indriani, R., Jumat, 8 Januari 2021, via video call WA).

"Sebenarnya saya tidak terlalu tahan atau terlalu menyukai belajar daring dalam masa pandemi ini, dikarenakan banyak sekali kendalanya. Namun dikarenakan untuk menaati protokol kesehatan saya dapat memaklumi dan mau tidak mau harus tahan terhadap masalah yang sedang dihadapi". 
(Lapenia, R., Jumat, 8 Januari 2021, via video call WA).

Transkrip wawancara di atas menunjukkan lemahnya ketahanan mahasiswa IAIN Curup dalam pembelajaran daring, yang mana hal ini terlihat dari kondisi bahwa mahasiswa merasa susah konsentrasi saat belajar daring karena banyak gangguan di rumah dan sekara sikap psikologis mereka tidak menyukai pembelajaran daring. Sejalan dengan Kruszewska dkk. (2020), kondisi pembelajaran daring berdampak pada lemahnya motivasi belajar yang diakibatkan kompleksitas pembelajaran daring yang cenderung memcahkan fokus belajar bagi murid. Selanjutnya, tema kelima dari data wawancara (kualitas psikologis mahasiswa menurun karena terbatasnya keterlibatan dalam dimensi sosial saat belajar) tergambarkan dalam cuplikan transkrip wawancara berikut:

"Dalam perihal ketahanan fisik, saya rasa tidak ada yang berubah atau dalam kata lain saat ini saya berada dalam kondisi normal. Namun perihal tentang psikis saya merasa tidak kuat karena sejujurnya sejak pandemi berlangsung saya merasa kesepian". (Puri, D., Jumat, 8 Januari 2021, via video call WA).

"Ketahanan fisik baik, alhamdulillah. Karena di dalam rumah saja, tidak ada yang terjangkit virus COVID-19 $\begin{array}{lcr}\text { mungkinakan } & \text { berbeda } & \text { jika } \\ \text { dibandingkan } & \text { dengan } & \text { kuliah }\end{array}$ offline/tatap muka yang kita tidak akan tahu akan adanya virus COVID-19 di sekitar kita. Ketahanan psikis mungkin yang kurang baik karena tidak dapat berbaur dengan sesama teman, apalagi untuk membahas materi di perkuliahan menjadi sulit karena terhalang jaringan". (Jamsit, H., Jumat, 8 Januari 2021, via video call WA).

"Untuk ketahanan fisik mahasiswa, saya rasa mahasiswa banyak mengalami kesulitan karena beberapa hal salah satunya jam kuliah yang sangat tidak menentu dan hal ini tentu akan sangat mempengaruhi ketahanan fisik siswa, belum lagi apabila ada dosen yang memberikan tugas berupa pembuatan vidio, hal itu akan sangat mempengaruhi kesehatan fisik siswa. Kemudian untuk ketahanan psikis dalam belajar saya rasa siswa memiliki banyak tekanan dalam belajar di masa pandemi. Dimulai dari penyesuaian belajar daring, kemudian keadaan dimana tidak memungkinkan untuk bertemu teman saat belajar tentu saja akan menambah beban pikiran siswa”. (Rahmadania, P., Jumat, 8 Januari 2021, via video call WA).

\begin{tabular}{cccc}
\multicolumn{2}{c}{ Tergambarkan } & dari & trasnskrip \\
wawancara di atas bahwa & ketahanan
\end{tabular} 
mahasiswa dalam belajar daring menurun, yang mana mahasiswa secara psikis merasa kesepian mungkin karena tipe belajar mereka yang cenderung berdimensi sosial, dan mereka merasakan penurunan kualitas fisik karena tugas-tugas kuliah yang kompleks. Hal ini sangat wajar terjadi karena gaya belajar para mahasiswa di IAIN Curup sebelumnya adalah berbasis pada kurikulum KKNI (Warsah dkk., 2020) yang mana kompetensi sosial (Warsah 2018), kompetensi religiusitas (Warsah 2020b; 2020c), dan kompetensi berfikir kritis mahasiswa (Warsah dkk., 2021) terlatih dalam prinsip pemebelajaran yang bermoda luring. Namun, ketika moda pembelajaran menjadi daring, semua kompetensi-kompetensi seperti yang disebutkan barusan akan susah tergali sebab sistem daring harus secara instan dilakukan karena pandemi secara otomatis menyulitkan dosen dan mahasiswa dalam menggali kompetensi-kompetensi tersebut. Belajar daring yang instan ini akhirnya membuat alur pembelajaran berfokus hanya pada tahap adaptasi sistem dan proses.

\subsection{Kendala yang Dirasakan Mahasiswa} Selama Pembelajaran Daring

Wawancara selanjutnya mengungkap tentang kendala yang dialami mahasiswa IAIN Curup dalam pembelajaran daring. Ada tiga tema yang merepresentasikan keseluruhan data terkait diskursus ini, tema-tema itu adalah 1) kendala sinyal, 2) kendala pembiayaan untuk membeli kuota internet, dan 3) kendala sulitnya mencari referensi dalam proses pembelajaran daring. Terkait dengan tema pertama (kendala sinyal), hal ini tergambarkan dalam transkrip wawancara berikut:

\section{"Tantangan pembelajaran daring} adalah ketersediaan layanan internet. Sebagian mahasiswa mengakses internet menggunakan layanan selular, dan sebagian kecil menggunakan layanan WiFi. Ketika kebijakan pembelajaran daring diterapkan di IAIN Curup, mahasiswa tak sedikit yang pulang kampung. Mereka mengalami kesulitan sinyal selular ketika di daerah masing-masing, jikapun ada sinyal yang didapatkan sangat lemah. Hal ini menjadi tantangan tersendiri dalam penerapan pembelajaran daring di IAIN Curup. Pembelajaran daring memiliki kelemahan ketika layanan internet lemah, dan intruksi dosen yang kurang dipahami oleh mahasiswa”. (Wawancara dengan Ningsih, 23 Desember 2020, Via video call WA).

"Bagi para siswa yang pulang ke kampung halaman, permasalahan terbesarnya terletak pada sinyal internet yang tidak begitu lancar". (Wawancara dengan Hasanah, Jumat, 8 Januari 2021, via video call WA).

“Terkadang masalah gangguan sinyal itu bukan datang dari mahasiswa saja melainkan dari pihak dosen juga. Sehingga pembelajaran tidak efektif". 
(Wawancara dengan Wardani, Jumat, 8 Januari 2021, via video call WA).

Transkrip wawancara di atas menunjukkan bahwa kendala sinyal internet sebenarnya bukan hanya menjadi masalah mahasiswa saja, namun juga masalah bagi dosen. Terkait dengan masalah sinyal internet yang dialami mahasiswa, karena setangah dari mahasiswa di IAIN Curup adalah mahasiswa dari kota lain, saat ada kebijakan pembelajaran daring, rata-rata mereka pulang kampung, dan pembelajaran daring di lakukan dari rumah mereka masing-masing. Kondisi ini membuat kendala sinyal internet menjadi lebih kompleks karena banyak mahasiswa yang menginformasikan bahwa sinyal Internet di daerah mereka susah diakses. Seperti yang tergambar dalam penelitian Dinh dan Nguyen (2020); dan Kruszewska dkk. (2020) bahwa ketersiadaan teknologi dan kompetensi menggunakan teknologi sangat menentukan keberhasilan pembelajaran daring. Terkait dengan tema kedua dari data wawancara (kendala pembiayaan untuk membeli kuota internet), hal ini tergambarkan dalam beberapa transkrip wawancara berikut:

"Selain terkendala sinyal yang sulit, saya pribadi terkendala dalam anggaran biaya untuk membeli kuota internet yang lebih besar daripada biasanya karena untuk perkuliahan terkadang harus menggunakan beberapa aplikasi yang memakan jumlah kuota internet yang cukup besar". (Wawancara dengan Dayang, Jumat, 8 Januari 2021, via video call WA)

"Tantangan lain yang dihadapi adalah kendala dalam pembiayaan pembelajaran daring. Mahasiswa mengungkapkan bahwa untuk mengikuti pembelajaran daring, mereka harus mengeluarkan biaya cukup mahal untuk membeli kuota data internet. Menurut mereka, pembelajaran dalam bentuk konferensi video telah menghabiskan banyak kuota data, sementara diskusi online melalui applikasi pesan instan tidak membutuhkan banyak kuota". (Wawancara dengan Lapenia, 23 Desember 2020, Via video call WA).

"Kendala saya terdapat pada kuota saya yang kurang memadai”. (Wawancara dengan Novita, Jumat, 8 Januari 2021, via video call WA).

"Yang pastinya saya kekurangan kuota internet, karena saya tinggal di kampung dan sinyal sangat jelek sekali. Sehingga kartu murah yang harganya terjangkau tidak memiliki sinyal di kampung saya. Alhasil saya harus menggunakan kartu yang harganya lumayan menguras kantong, sedangkan kuota dari kampus hanya diberikan sekali untuk sebulan dan sekarang saja sudah habis masa 
berlakunya". (Wawancara dengan Mentari, Jumat, 8 Januari 2021, via video call WA).

\section{Berdasarkan transkrip wawancra di} atas, terlihat bahwa mahasiswa merasa terkendala dalam pembiayaan untuk membeli kuota internet. Sejak pembelajaran daring berlangsung, pengeluaran mahasiswa tentu bertambah. Terlihat bahwa sebagian besar mahasiswa cenderung menggunakan kuota dari pada wifi untuk mengakses internet. Selanjutnya terkait dengan tema ketiga (kendala sulit mencari sumber belajar untuk pembelajaran daring), salah satu mahasiswa menginformasikan sebagai berikut:

"Saya pribadi memiliki kecepatan sinyal yang cukup, namun kendala saya adalah sulitnya menemukan sumber-sumber buku untuk referensi membuat tugas. Karena di perpustakaan online, terkadang tidak ada referensi yang sedang dicari”. (Wawancara dengan Shaputri, Jumat, 8 Januari 2021, via video call WA).

Sebenarnya, kendala yang diungkapkan oleh Shaputri pada transkrip di atas, apabila diinterpretasi, bukanlah kendala karena referensi di internet sulit untuk dicari, namun ini merupakan kendala kompetensi berteknologi mahasiswa yang cenderung masih lemah. Apabila mampu memanfaat internet dengan baik, tentu saja referensi belajar yang tak terbatas bisa diakses. Hal ini ditekankan oleh Thongsri dkk. (2019) bahwa kompetensi penggunaan teknologi seperti internet dan berbagai aplikasi pembelajaran daring merupakan faktor utama keberhasilan pelajar dalam mengikuti pembelajaran daring.

\section{KESIMPULAN}

Penelitian ini mengungkap dua set informasi, yaitu tentang ketahanan mahasiswa IAIN Curup dalam pembelajaran daring, dan kendala yang dialami mahasiswa IAIN Curup selama mengikuti pembelajaran daring. Terkait ketahanan mahasiswa IAIN Curup dalam pembelajaran daring, ketahanan belajar mahasiswa menurun dan melemah. Hal ini tergambarkan dalam kondisi, yang pertama, aspek psikologis mahasiswa yang tertekan, secara fisik kesehatan mata mereka menurun, dan mereka mengalami sakit kepala. Kedua, ketahanan fisik mahasiswa menurun hingga menyebabkan kualitas psikis mereka menurun. Ketiga, secara psikologis, mahasiswa merasa bosan. Keempat, secara psikologis, mahasiswa susah berkonsentrasi. Kelima, kualitas psikologis mahasiswa menurun karena terbatasnya keterlibatan dalam dimensi sosial saat belajar. Selanjutnya, terkait dengan kendala yang dialami mahasiwa IAIN Curup selama pembelajaran daring, mereka mengalami kendala pada sinyal internet, 2) kendala pembiayaan untuk membeli kuota internet, dan 3) kendala sulitnya mencari referensi dalam proses pembelajaran daring, yang mana ini dikategorikan sebagai kendala lemahnya kompetensi berteknologi mahasiswa. 
Penelitian selanjutnya diharapkan untuk mencari solusi agar ketahanan mahasiswa dalam pembelajaran daring bisa ditingkatkan, dan juga berusaha agar kendalakendala teknis, psikologis, dan psikis dalam pembelajaran daring dapat ditanggulangi.

\section{DAFTAR PUSTAKA}

Barclay, Corlane, Charlette Donalds, and Kweku Muata Osei-Bryson. 2018. "Investigating Critical Success Factors in Online Learning Environments in Higher Education Systems in the Caribbean*." Information Technology for Development 24 (3): 582-611. https://doi.org/10.1080/02681102.201 8.1476831 .

Burke, Katie, and David Cleaver. 2019. "The Art of Home Education: An Investigation into the Impact of Context on Arts Teaching and Learning in Home Education." Cambridge Journal of Education, 118. https://doi.org/10.1080/0305764X.201 9.1609416 .

Creswell, John W. 2007. Qualitative Inquiry \& Research Design: Choosing among Five Approaches. 2nd ed. USA: SAGE publications, Inc.

Dinh, Linh P, and Trang T Nguyen. 2020. "Pandemic, Social Distancing, and Social Work Education: Students' Satisfaction with Online Education in Vietnam." Social Work Education, 1-
10.

https://doi.org/10.1080/02615479.202 0.1823365 .

Ellis, Viv, Sarah Steadman, and Qiming Mao. 2020. "Come to a Screeching Halt': Can Change in Teacher Education during the COVID-19 Pandemic Be Seen as Innovation?" European Journal of Teacher Education, 1-14. https://doi.org/10.1080/02619768.202 0.1821186 .

Firman, and Sari Rahayu Rahman. 2020. "Pembelajaran Online Di Tengah Pandemi Covid-19." Indonesian Journal of Educational Science 2 (2): 81-89.

Fraenkel, Jack R, Norman E Wallen, and Helen H Hyun. 2012. How to Design and Evaluate Research in Education. 1221 Avenue of the Americas, New York, NY 10020: McGraw-Hill Companies, Inc. https://doi.org/10.1017/CBO97811074 15324.004.

Gil-Glazer, Ya'ara. 2017. "Visual Culture and Critical Pedagogy: From Theory to Practice." Critical Studies in Education, 1-20. https://doi.org/10.1080/17508487.201 7.1292298 .

Gómez-Rey, Pilar, Elena Barbera, and Francisco Fernández-Navarro. 2016. “Measuring Teachers and Learners' Perceptions of the Quality of Their 
Online Learning Experience." Distance Education 37 (2): 146-63. https://doi.org/10.1080/01587919.201 6.1184396.

Hernández-Lara, Ana Beatriz, and Enric Serradell-López. 2018. "Student Interactions in Online Discussion Forums: Their Perception on Learning with Business Simulation Games." Behaviour and Information Technology $37 \quad$ (4): 419-29. https://doi.org/10.1080/0144929X.201 8.1441326.

Huang, Qiang. 2019. “Comparing Teacher's Roles of F2f Learning and Online Learning in a Blended English Course." Computer Assisted Language Learning $32 \quad$ (3): 190-209. https://doi.org/10.1080/09588221.201 8.1540434 .

Kidd, Warren, and Jean Murray. 2020. "The Covid-19 Pandemic and Its Effects on Teacher Education in England: How Teacher Educators Moved Practicum Learning Online Online.” European Journal of Teacher Education, 1-17. https://doi.org/10.1080/02619768.202 0.1820480 .

Kruszewska, Aleksandra, Stanisława Nazaruk, and Karolina Szewczyk. 2020. "Polish Teachers of Early Education in the Face of Distance Learning during the COVID-19 Pandemic - the Difficulties Experienced and
Suggestions for the Future." Education $3-13$, $1-12$. https://doi.org/10.1080/03004279.202 0.1849346 .

Martin, Florence, Chuang Wang, and Ayesha Sadaf. 2018. "Student Perception of Helpfulness of Facilitation Strategies That Enhance Instructor Presence, Connectedness, Engagement and Learning in Online Courses." Internet and Higher Education 37 (March 2017): $52-65$. https://doi.org/10.1016/j.iheduc.2018.0 1.003.

Miles, Mathew B., A. Micheal Huberman, and Johnny Saldana. 2014. Qualitative Data Analysis: A Methods Sourcebook. Thousand Oaks, California 91320: SAGE Publications, Inc.

Morgan, Hani. 2020. "Best Practices for Implementing Remote Learning during a Pandemic." The Clearing House: A Journal of Educational Strategies, Issues and Ideas 93 (3): 134-40. https://doi.org/10.1080/00098655.202 0.1751480 .

Morganna, Ruly, Sumardi, and Sri Samiati Tarjana. 2020. "Tertiary English Students' Attitudes towards Intercultural Language Learning." Indonesian Journal of Applied Linguistics $\quad 9 \quad$ (3): $\quad 657-65$. 
https://doi.org/10.17509/

ijal.v9i3.23216.

Pittard, Elizabeth. 2016. "Who Does Critical Pedagogy Think You Are? Investigating How Teachers Are Produced in Critical Pedagogy Scholarship to Inform Teacher Education." Pedagogies: An International Journal, 1-21. https://doi.org/10.1080/1554480X.201 5.1066679 .

Santos, Henrique Lemos dos, and Cristian Cechinel. 2019. "The Final Year Project Supervision in Online Distance Learning: Assessing Students and Faculty Perceptions about Communication Tools." Behaviour and Information Technology 38 (1): 65-84.

https://doi.org/10.1080/0144929X.201 8.1514423 .

Schwimmer, Marina. 2019. "Rorty, PostCritical Pedagogy and Hope: A Response." Ethics and Education 14 (4): 497-504. https://doi.org/10.1080/17449642.201 9.1669355 .

Thongsri, Nattaporn, Liang Shen, and Yukun Bao. 2019. "Investigating Factors Affecting Learner's Perception toward Online Learning: Evidence from ClassStart Application in Thailand." Behaviour and Information Technology 38 (12): 1243-58.
https://doi.org/10.1080/0144929X.201 9.1581259 .

Warsah, Idi. 2018. "Pendidikan Keimanan Sebagai Basis Kecerdasan Sosial Peserta Didik: Telaah Psikologi Islami." Jurnal Psikologi Islami 4 (1): $1-16$.

2020a. "Forgiveness Viewed from Positive Psychology and Islam." Islamic Guidance and Counseling Journal 3 (2): 108-21. https://doi.org/10.25217/igcj.v3i2.878.

. 2020b. "Islamic Psychological Analysis Regarding Raḥmah Based Education Portrait at IAIN Curup." Jurnal Psikologi Islami 6 (1): 29-41. 2020c. "Religious Educators: A Psychological Study of Qur'anic Verses Regarding Al-Rahmah." Al Quds 4 (2): 275-98. https://doi.org/10.29240/alquds.v4i2.1 762.

Warsah, Idi, Imron, Siswanto, and Okni Aisa Mutiara Sendi. 2020. "Strategi Implementatif KKNI Pendidikan Islam Di IAIN Curup Dalam Pembelajaran.” Jurnal Tarbiyatuna 11 (1): 77-90.

Warsah, Idi, Yusron Masduki, Mirzon Daheri, and Ruly Morganna. 2019a. "Muslim Minority in Yogyakarta: Between Social Relationship and Religious Motivation." Qudus International Journal of Islamic Studies 7 (2): 1-32. 
https://doi.org/10.21043/qijis.v7i2.687

3.

—. 2019b. "Muslim Minority in Yogyakarta: Between Social Relationship and Religious Motivation." Qudus International Journal of Islamic Studies 7 (2): 1-32. https://doi.org/10.21043/qijis.v7i2.687 3.

Warsah, Idi, Ruly Morganna, Muhamad Uyun, Hamengkubuwono, and Muslim Afandi. 2021. "The Impact of Collaborative Learning on Learners' Critical Thinking Skills.” International Journal of Instruction 14 (2): 443-60.

Warsah, Idi, and Muhamad Uyun. 2019. "Kepribadian Pendidik: Telaah Psikologi Islami." Psikis : Jurnal Psikologi Islami 5 (1): 62-73. https://doi.org/10.19109/psikis.v5i1.31 57.

Wei, Huei Chuan, Hsinyi Peng, and Chien Chou. 2015. "Can More Interactivity Improve Learning Achievement in an
Online Course? Effects of College Students' Perception and Actual Use of a Course-Management System on Their Learning Achievement." Computers and Education 83: 10-21. https://doi.org/10.1016/j.compedu.201 4.12.013.

Wei, Yao, Jinjing Li, and Yong He. 2019. "Research on the Influencing Factors of College Students ' Use of Online Learning Platform from the Perspective of Customer Perception Research on the Influencing Factors of College Students' Use of Online Learning Platform from the Perspective of Customer." Journal of Physics, 1-8. https://doi.org/10.1088/17426596/1345/4/042080.

Zhang, Dongsong, J. Leon Zhao, Lina Zhou, and Jay F. Nunamaker. 2004. "Can ELearning Replace Classroom Learning?" Communications of The ACM 47 (5): 74-79. 